DOI: 10.7596/taksad.v3i3.309

\title{
İlimlerin Tasnifi Tarihi
}

\section{Ebülfez Elçibey* \\ Çev: Muhammet Kemaloğlu}

Öz

Klasik dönemden modern döneme geçişle birlikte bazı anlayışlar değişmiştir. Modern dönemle birlikte Batı toplumunda varlık probleminin (ne olduğu, nereden geldiği, nereye gittiği vs.) ihtiyaç olmaktan çıktığı, dolayısıyla felsefenin, genelde bilimlerin özelde sosyal bilimlerin gündeminden düştüğü, akıl yoluyla topluma ilişkin rasyonel ve bilimsel yasaların tayin edilmesinin öne alındığı dikkati çeker. Hakikatin, bilginin ve doğrunun ne olduğu ve nasıl tayin edileceği konusunda bir değişimin olduğu, bu bağlamda Sosyal bilimlerin kesin, sayısal verilere dayalı, ispatlanabilir önermelerle şekillenen, toplumsal meşruiyeti bulunan Fen bilimlerine yaklaşırken, felsefeyi ötekileştirdiği ve felsefeyle arasına kesin hatlar çizdiği görülür. Ebülfez Elçibey’in bu makalesinde ise ilimlerin tasnifi tarihi ele alınmıştır.

Anahtar Kelimeler: Ebülfez Elçibey, İlim, Tasnif, Klasik Dönem, Modern Dönem.

\section{The History of Science Classification}

\section{Abstract}

The understandings of Classical period changed a lot with the beginning of the modern era. With the beginning of the modern era the problem of being (what it is, where it came

\footnotetext{
* Obülfəz Elçibəy, Azərbaycandan Başlayan Tarix, Tərtibçi və Redaktor: Mircəlal Yusifli, Bakı, Adiloğlu Nəşriyyatı, 2003, s.83-91.
} 
from, where you went, etc..) was no longer perceived as a problem, and therefore philosophy dropped from the agenda of the general sciences and social sciences in particular. The Mental, rational and scientific laws of society were taken into consideration instead of philosophy. In this context, the understanding of truth and the knowledge of truth changed. Social sciences have gradually turned away from the philosophy. Exact numeric data, based on the provable propositions shaped the social legitimacy of the approach to the social sciences like as natural sciences. In this article Abulfez Elchibey of the classification of sciences is discussed.

Keywords: Ebulfez Elchibey, Science, Classification, ClassicalPeriod, Modern Period.

\section{GíRiș}

Bilgi bütün beşeriyet tarihi boyunca çok mürekkep ve karışık bir yoldan geçip gelmiş ve şimdi ise ilmi bilgiler öyle bir konuma sahip olmuştur ki, onsuz herhangi bir çağdaş cemiyet tasavvur edilememektedir. İlim çok istisnai ve daima ilerleyen müteşekkil bir güce sahip bir yapıya ve güce döndürülmüştür. Çağdaş dünyada ilmin kazandığı güç, bundan sonra fezada, tabiatta mevcut olan fevkalade güçler ile mukayese edilebilir. Sırf buna göre de dünyaca tanınmış büyük âlimlerden tutun da, diyebiliriz ki, sayısız âlimler, fizikçiler, riyaziyatçılar, filozoflar, tarihçiler: ilim uzmanları vb. bu istisnai gücün nasıl ortaya çıktığını, nasıl inkişaf ettiğini, hangi hususiyetlere malik olduğunu, mevcut gücünü, ihtiyat gücünü, kuruluşunu, geleceğini vb. öğrenmeye ve belirginleştirmeye çalışır, daha doğrusu bu "kozmik hadiseye" çevrilmiş insan bilgisini yine de ilmin kendi gücü ile öğrenmek istiyorlar.

Bu sahada çalışan âlimler bu şekildeki genelleşmiş bir fikri tekrar tekrar kaydederler ki, ilim kendisinin birkaç bin yıllık tarihi ile birleşerek hareket ve inkişaf etmektedir, buna göre de onun tarihi her zaman, inkişafının her yeni aşamasında (bu aşamalar çok sürekli olarak değişir) yeniden, tekrar tekrar öğrenilmelidir ve ilmin tarihi bugünü ile aynı yerdedir. Şöyle diyebiliriz, ilmin dünü, bugünü ve yarını birbirinden ayrılamaz ve ilmin inkişafında tek bir zaman anlayışını ortaya çıkarır ve buradan şöyle neticeye varılır, ilmin “dünü” ile “bugünü” muasırlık bakımından aynıdır. Ona göre de ilmin tarihi öğrenilirken onun bugünü ve yarını da öğrenilir.

İmin tasnif tarihi, ilmin tarihinin ana hattıdır. 
İlmin tasnif tarihini öğrenmek, her zaman en aktüel ve en gerekli bir mesele olarak kabul edilmiş ve kabul edilmektedir. Bu kesindir. Ancak bu mesele o kadar ciddi, mürekkep, karmaşık ve o kadar muhtelif yönlüdür ki, onu tek bir sisteme sokmak oldukça zordur. Bütün bunları dikkate alarak, konuya başlarken bir dizi açıklamalar getirmek mecburiyetindeyiz.

Bu zorluklar nereden başlar?

İlk olarak ilim sözünün kendisinden. Belli olduğu gibi, bu söz muhtelif devirlerde kendi anlamını ve algılanışını sık sık ya değiştirmiş, ya da ona muhtelif tarif ve tanımlamalar atfedilmiştir. Ona göre de sorudan soru çıkar:

\section{“Orta asırlarda şarkta ilim denince ne anlaşılıyordu, şimdi ne anlaşıllyor?}

Bunun çözümü ona göre o kadar gereklidir ki, orta asırlarda binlerce âlimin ilim saydığı birçok bilgiler şimdi ilim sayılmıyor. Ya da, öylece orta asırların kendisinde bir dizi âlimler bazı bilgileri ilim saydığı halde, başkaları onları bu veya bir başka ilmin bölümü, ya da, mevzusu saymıştır. Çoğu zaman bilgi, ilim, fen, mevzu, sanat anlayışları aynılaştırılmıştır. Buna en iyi örnek olarak XVI. yüzyılda yaşamış, büyük Türk âlimi Hüsameddin Ahmed Taşköprülüzade’nin (1495-1561) “Mutluluk Anahtarı ve Ağalık Çırağı” eserini gösterebiliriz. $\mathrm{Bu}$ eseri müellifin oğlu Arapçadan Türkçeye-Osmanlıcaya çevirdiğinde onu "İlimlerin Mevzuları (Çaldak, 2005: 115-146) ${ }^{1 \text { ” }}$ olarak isimlendirmiştir.

$\mathrm{Bu}$ eser hakkında yazılar yazan sonraki asırların ve çağdaş devrin âlimleri, hiç ayırt etmeden orada "500 ilimden", bahsedildiğini belirtirler. Ancak bir ilim adamı gibi bu esere bakıldığında anlaşılıyor ki, onların çoğu ilim değil, ya sanat, ya ilim sayılamayacak bilgidir, ya da başka bir ilmin sahasıdır, mevzusudur vb.

Buna göre de araştırıcı iki yol ayrımında kalır; eğer araştırmaya orta asır âlimlerinin ilime bakışı açısıyla bakarsa tetkikatın gidişi başka, yok eğer yalnız çağdaş bir bakış açısıyla bakarsa daha başka şekilde anlaşılır ve bu sonuncu usul tarihe bakış olarak kabul edilebilir. Zaten çağdaş ilim tarihçisi ister istemez orta asra kendisinin şimdiki zamandaki şekillenmiş görüşünün havasını da katar.

\footnotetext{
1 Mevzuatü’l Ulûm, Taşköprülüzâde'nin tasnifi genel hatlarıyla şöyledir: I.Kitâbî:Edevâtu'l-hat, kavâninu'l-kitâbet, tahsinînü'l-hat, tertîbu'l-hurûf, vb.

II.İbârî:Mehâricu'l-hurûf, lügat, vaz', iştikâk, tasrîf, nahiv, me’ânî, aruz, vb.

III. Zihnî: Mantık, nazar, cedel, hilâf, âdâbu'd-ders.

IV.Aynî:

A.Hikmetu'n-nazariyye:

1. Ulumu'l-ilâhiyye,

2.İlmu't-tabiî (tıb, baytara, maadin, kimyâ, sihir vb),

3.Ulûmu'r, riyâziye (hendese, hey'et, vb),

B.Hikmetu'lameliyye (ahlâk, siyâset vb),

C.Ulûmu'ş-şer'iyye (usûlu'd-dîn, kırâ'at, hadîs, tefsîr).MK..
} 
Ancak bu veya başka orta asır âliminin fikrini çağdaş bakışla "bozmak-karıştırmak" ne kadar kendisini anlaşılır kılabilir?

Ona göre de burada üçüncü bir ortak yol bulunmalı, tarihi çok büyük bir ihtiyatla birlikte ele alarak, ona karşı yanlış yapmamaya (zaten birçok konuda yanlışlar yapılıyor) çalışılmalıdır. Bunun için her iki bakış (orta asırların ve çağdaş devrin) hakkında burada umumi de olsa açıklama yapılması çok mühimdir.

Birincisi, ilim hakkında çağdaş faraziyelere geçici de olsa bir bakalım ki, bu bizce daha uygundur ve meselenin doğru anlaşılması ve kıymetlendirilmesinde bize yol gösterecektir. Önceden belirtelim ki, eser Azerbaycan Türkçesinde yazıldığı için, burada ilk önce bilgi, ilim vb. hakkında dilimizdeki anlayışları aydınlatıp ve netleştirerek, yeri geldikçe başka dillerdeki anlayış ve tariflerle mukayese edeceğiz.

Bilindiği gibi "bilgi” sözü kendi anlayış ve manasına göre “ilm” sözünden daha geniştir ve eskidir. Bu birçok başka dillerde de böyledir. "Bilgi" anlayışı "ilm” anlayışından farklı olsa da, çoğu zaman aynı manada kullanılmış ve şimdi de kullanılmaktadır. Bu sözler aynı zamanda o kadar yakın anlayışlardır ki, "bilgi” sözü “ilim” sözü ile veyahut aksine, “ilim” sözü "bilgi” sözü ile izah edilir. Gerek büyük "Kül Tegin Abidesi”nde "bilir biligim bilmez tek boldu" ve gerekse de "Kitabi Dede Korkud”da "bilir biligim bilmez gibi oldu" ifadeleri bütün mana farklılıkları ile beraber, daha çok “bilgi” anlayışını bildirir.

"Bilgi” sözü kadim ve orta asırlarda Azerbaycan Türkçesinde "bilgi” gibi de kullanılırdı. Bu kökten oluşan "bilge" ve "bilici” sözleri "müdrik adam", "hikmet sahibi" manalarına daha çok yakın olsa da, "âlim" manasını da kendi içerisine alırdı. Mesela, kadim Kül Tegin abidelerinde rastladığımız, Bilge Hakan, “Dedem-Korkud” kitabında Dede Korkud (o, bütün Oğuzun bilicisi idi) müdrik evliya etkisi verseler de, kendi faaliyetlerinde daha çok Farabi'nin, Nizami'nin tasvir ve arzu ettikleri, ideal devletin idaresinde iştirak eden hekim filozofa yakındırlar.

“Bilgi” sözü Azerbaycan Türkçesinde bu güne kadar kendi manasını koruyarak, hem bilgi, hem de ilim manasında kullanılır. Orta asırlarda Arapçadan gelen “ilim” sözü ise bilgisin eş anlamlısı gibi kullanılmıştır. Umumiyetle dilimizde "bilgi” sözünün kendisi çok manalı olmakla beraber, hem de bilgi, ilim ve bilgi, fen şekillerinde de kullanılır. Ansiklopedi ve izahlı sözlüklerde bu sözlerin biri bir diğeri ile izah edilir, manalandırılır. "Bilgi-okumak veya tecrübe neticesinde elde edilen malumat; ilim” (Azerbaycan Dilinin İzahlı Lügati, 1964: 270). 
“İlim-tabiat ve cemiyetin inkişafindaki kanuna uygunlukları ve objektif âleme tesiri usullerini meydana çıkaran bilgiler sistemi ve bu bilgilerin ayrıca sahası... Okumakla elde edilen bilgi, malumat vb. demektir” (Azerbaycan Dilinin İzahlı Lügati, 1980: 203). Klasik Azerbaycan edebiyatında, özellikle de şiirde bilginin, ilmin çok geniş, muhtelif faklılıklarla izahı, tarifi, tayini yapılmıştır ki, bu konunun kendisi ayrıca bir araştırma konusudur. Çağdaş Azerbaycan Türkçesinde “bilgi”yle “ilim” çok yakın ve hatta aynı manalarda kullanılsa da, onlar arasında fark vardır. Şöyle ki, bilgi daha geniş manadadır, ilim ise bilgiye göre genel bir anlama gelir. İşte bundan dolayıdır ki bilgi ikiye (yüksek bilgilere ve ilmi bilgilere) ayrılır. Şöyle diyebiliriz ki, ilim umumi bilginin içerisinde, hususi, seciyevi bilgidir, daha doğrusu ilim, bilginin içerisinde olan ayrıca öyle büyük bir olgudur ki, hem bilgiden gıdalanır, hem de inkişaf ederek bilgiyi büyütür, yenileştirir. Sovyet ilim adamı V.C. Kelle’nin sözleri ile söylersek: "İlim, bilindiği gibi, sadece bilgiler sistemi değil, yeni bilgiler kazanmakla ilgili olan idraki nazari faaliyettir” (Nauka i kultura, 1984: 10).

Burada bilgi ve ilmin tarifini değil, bu iki anlayışın birbiriyle münasebeti ve dilimizdeki mana farklılıkları gösterilmeye çalışılmaktadır. Bir de şu husus belirtilmelidir ilim sözü daha çok iki anlayışta kullanılır:

1. Genel olarak ilim; bu arada buna büyük harfle yazılan İLİM de diyebiliriz.

2. Ayrı ayrı mevzuları, daha doğrusu araştırma konusu olan ilimler.

Bu sonuncu ilim daha çok "fen" sözü ile aydınlatabilir.

Birinci manada ilim, bilginin sahası ise de, ikinci manada ilim ilmi bilginin muayyen kısmına aittir. Bilgiyle ilim arasında dilimizde oluşan bu anlayış farkı son asrın mahsulüdür. Gerek uzak geçmişte, gerekse de orta asırlarda bilgiyle ilim hiç bir dilde manaca birbirinden ayrılmıyordu. Avrupa'da “ilim” sözü bugünkü anlayışı XIX. asrın birinci yarısından kazanmaya başlamıştır. Daha doğrusu 1831'de Britanya Birliği kurulduğu zaman “ilim” (science-cmuence) bugünkü manada kullanılmaya başlamış, daha çok kendi asıl manasını XIX. asrın sonlarında bulmuştur. O zamana kadar “cmuence” terimi “bilgi”, “akıl”, “okumak” manasında kullanılırdı (Nauka i kultura, 1984: 201-202).

Latinceden alınmış bu söz İtalyan, Fransız, İngiliz ve başka Avrupa dillerinde ayrı ayrı telaffuzla kullanılır. Hatta Rusça yazılan ilimciliğe ait çağdaş eserlerde bu terime sık sık rastlanılır. Rusçada “bilgi” ve “ilim” (znanie, nauka) sözleri çoğu zaman bir biri ile açıklanır ve aynı anlayışta kullanılır: "nauka-1. sistema znaniy. 2. Navıki, znaniya poluçaemıe 
çelovekom v rezultate obuçeniya ili jiznennoqo opıta. U starikov surovıx perenimal ya hıtriyu nauku, kak stroit xatı, kak sajat derevya" (Slovar Russkoqo Yazıka, 1983: 409).

Buradan da anlaşılmaktadır ki, “ev yapmak, ağaç ekmek” bile ilim sayılmıştır. Dal'ın izahlı sözlüğünde ilim: "talim, öğrenme ve tahsil” (uçenie, vıuçka, obuçenie) sözleri ile izah edilir ve misal olarak "Hayat-ilmdir, o tecrübe ile öğretir" (jizn nauka, ona uçit opıtom) ifadesini kullanır.

Böylelikle, diyebiliriz ki, bütün dillerde bilgi ve ilim sözleri çoğu yerde birbirinin yerine kullanılır ve çok farklı anlamlar verir. Araştırmada bilgi ve ilim sözlerinden bu şekildeki bir izahla bahsetmek yersiz görünebilir, Ancak mesele hiç de böyle değildir. Mevzudan da anlaşılmaktadır ki, araştırma, ilimlerin orta asırlarda tasnifatı problemi üzerinde yapılmaktadır. Buna göre de ilim sözünün sınırları tam olarak belirlenmelidir ki, anlaşılmazlık olmasın. Meselenin esas zorluklarından birisi de şudur ki, bir âlimin ilim saydığı bilgi türünü, başka bir âlim ilim olarak kabul etmemesidir. Bu durumun esas sebebi ise bilgi terimi ile ilim teriminin aynı sözle ifade edilmesidir. Daha doğrusu ilim sözünün bilgiden ayrılıp gitgide bağımsız bir anlayış kazanması sonraki asırların mahsulü olduğundan karışıklıklar sonradan oluşmuştur.

Ona göre de araştırmacı her zaman zor bir muhakeme karşısında kalır. Bu veya başka bir ilmin ayrı ayrı sahalarına da ilim adını veren orta asır âlimleri neleri yanlış veya doğru yapmışlar?

Ona göre de ister-istemez sözün kendisinin hangi anlayışlarda kullanıldığını açıklamak daha da öne çıkıyor ve bunlar olamadan araştırmayı devam ettirmek mümkün olmaz.

Bilindiği gibi bugünkü ilmin esas kaynakları kadim Yunanistan ilmi olmuştur. Yunanistan ilminin Sümer, Babil ve Mısır ilmi üzerinde ortaya çıktığı da kesindir. Ancak onlar hakkında tam bir tasavvur hala da bilinmemektedir. Galiba, tarih ilminin inkişafı ile bağlı olarak gelecekte tasavvurumuz bir o kadar da tamamlanacaktır (Sümerler bilgiye "zu: su” diyordular). Şimdilik bugün kabul edilen şudur ki, kadim dünya ilmi Yunanistan'da birleşmiştir, daha doğrusu sentez edilmiştir. İlmin, daha doğrusu bilginin geniş, devrine göre detaylı tahlili kendi karşılığını Aristoteles'in yaratıcılığında bulmuştur. Burada bilgi hem sıradan, hem de ilimi-aynı manada, bir sözle, episteme (episteme ${ }^{2}$ ) sözü ile ifade edilir. Ona göre de kesin olarak diyemiyoruz ki, Aristotales episteme diyince neyi kastediyor, bilgiyi mi,

2 Episteme, felsefe tarihindeki genel kullanımıyla, bilgi anlamına gelmektedir.Felsefenin alt disiplinlerinden biri olan epistemoloji'de episteme kavramından gelir.MK.. 
yoksa ilmi mi? Aristoteles'in eserleri dikkatle gözden geçirildiğinde, belli oluyor ki, onun epistemesi çok anlamlıdır ve şimdiki bizim tasavvurumuzdan çok farklıdır:

a. Birincisi, Aristoteles'in epistemesi bilgi, ilim, ilmi bilgi, ilimlik, fen, sanat, talim vb. manalar vermekte, onun karşıllı̆ı çağdaş tercümelerde bu muhtelif anlayışlarla gösterilir (bizce bu tür tercüme bir o kadar de başarılı sayılmamalıdır, çünkü ne derecede olursa olsun Aristoteles'i muasırlaştırmak anlamına geliyor ki, bu da bir taraftan şimdiki okuyucuya yardım etse de, başka bir yandan Aristoteles'i gerçekten anlamaya mani oluyor).

b. İkincisi, Aristotales sanat, ince sanat, poetikayı da episteme sayıyor ki, bunu iki türlü aydınlatabiliriz:

1.Sanat ilim değil, muayyen bilgi ve başarının mahsulüdür;

2.Her hangi bir sanat mahsulünün ortaya çıkmasında muayyen ilimlerden, örnek: geometri, matematik vb. istifade edilir.

c. Üçüncüsü, bilindiği gibi kadim devirde ve orta asırlarda bilgi sahası sayılan bir dizi yaratıcı faaliyet, şimdi ilim sayılmıyor. Örnek: şiir (poetika) vb. bu ise onunla bağlıdır ki, muhtelif devirlerde ayrı ayrı alimler bilgi ve ilim anlayışını muhtelif tasavvur etmiş, kendilerinin beyinlerinde yarattıkları belirleme esasında onu kabul etmişler (Aristotel, 1976: 65-67 119 180-182 284-287; II. cilt, 1978: 257-258, 261-262, 273-278, 280-283; IV cilt, 1983: 54-55, 60, 173-174 178-182, 281-293, 297-300; Lukanin, 1984: 4-7,160-181). Bu, durum bugün de devam etmektedir ki, bunun hakkında bir az sonra konuşulacaktır.

\section{Peki, orta asırlarda Yakın ve Orta şarkta bilgi ve ilim nasıl anlaşıllyordu?}

$\mathrm{Bu}$ araştırmanın devamında aynı mesele geniş bir şekilde izah edilecektir. Ancak burada geçici de olsa belirli bir malumatın verilmesi zaruridir. Bilindiği gibi İslam dinini kabul etmiş halklar ilme ait yaratıcılıklarını ara sıra Türkçe ve Farsça olarak ifade etseler de esasen Arapça yazmışlar ve her üç dilde de bilgi ile ilim sözünü, birkaç yaratıcılık sahalarını tek bir terimle "ilim” sözü ile ifade etmişlerdir. Ancak buna bakmayarak Yunancadaki episteme gibi, Arapçadan çıkma "ilim" sözü de daha çok bizim bugün anladığımız manada "bilgi”" anlayışını vermektedir. Bu konu hakkında, daha doğrusu Yakın Şark dillerinde, özellikle de Arapça yazılı edebiyatta "İlim”in verdiği manalara ve umumiyetle ilmin yeri meselesine hasredilmiş "Bilginin Zaferi" ${ }^{3 ،}$ kitabı en kıymetli tetkikat sayılmalıdır. Büyük şarkşünas Frans Rouzental küçük anlaşmazlıklara (bunlar olmadan da anlamak mümkün 
değil, biz ne birçok yanlışlardan kendimizi kurtarmaya çalışsak da, yine de onların izi kalıyor, bu izleri anlaşmazlık saymayabiliriz de) bakmayarak karşısında koyduğu meselenin uhdesinden büyük bir başarıyla gelebilmiştir ${ }^{4}$. Biz eser hakkında yeri geldikçe kendi fikrimizi önceden bildireceğiz. Şimdilik şunu diyelim ki, Rouzental ilim fenomenini "bilgi”" anlayışında almakla doğru davranmıştır. Müellif: Arapça “İlm” bizim “bilgiye” kifayet derecede iyi tercüme olunuyor. Ancak "bilgi” "İlim”in bütün delil ve heyecan mazmununu ifade edemiyor, şöyle ki, “ilim” (ilm) İslamda Müslüman medeniyetine kendisinin seciyevi görkem ve boyasını vermiş yönlendirici görüşlerden (konsepsiyalardan) biridir” (Rouzental, 1978: 20). Müellif, fikrinin devamında ilave ederek diyor ki, hatta tevhit ve dini terimleri de böyle “istifadesinin derinliğine ve genişliğine göre ilim (sözü ile) bir arada olmuyor” (Rouzental, 1978: 20).

“İlm” bir terim gibi özünde çok geniş, derin, çok anlamlı anlayışları birleştirdiğinden ve Azerbaycan Türkçesinde de öyle aynı manada, aynı şekilde -ilm- kullanıldığından bu araştırmada "ilim" diyince çağdaş anlayışla değil, orta asırların anlayışında verilecektir ki, "bilgi”" anlayışı da onun içinde olacaktır. "İlm”in bu kadar çevik ve değişken olması birinci zorluğu ortaya çıkarıyorsa, orta asırlarda ona verilen tayin ve tariflerin de oldukça fazla ve türlü türlü olması ikinci zorluğu yaratıyor.

Yeri gelmişken gösterelim ki, daha yeni, ilim (science, nauka vb.) ${ }^{5}$ kendi anlamını ve yerini tam olarak bulmuştur, ona muhtelif yönlerle birlikte, sayısız tarif ve tayinat yapılır. Neticede bu tarif ve tayinatların (hepsini bir yere toplamak mümkün değil) birkaçını karşılaştırmakla sadece araştırmacı, hatta büyük filozoflar, ilim adamları da çıkılmaz duruma düşüyorlar. Şöyle ki, hatta birçok âlimler öyle bir noktaya gelip çıkıyorlar ki, onların tariflerinin bazısına göre felsefe, başkalarına göre de edebiyat, tarih, hatta mantık ve riyaziyat da ilim sayılmıyor. Eğer ilime, ilmin bugünkü tarifine (ve yahut tariflerine) göre yanaşırsak, ister istemez şöyle bir neticeye gelmeliyiz ki, kadim ve orta asırlarda, hatta yeni devirde Çin ve Japonya'da ilim olmamıştır. Peki, bugün anladığımız manada, ilim, Yunanistan'dan başlayan ananenin çerçevesinde ve esasında Yakın ve Orta Şarka, sonra Avrupa’ya geçerek gelişe gelişe şekillenmiştir. Çin, Japonya ve onlarla komşu ülkelerde ise yüksek yeri yazılı ve şifahi edebiyat alıyor, bilginin yegâne temsilcisi yerinde konuşuyor, ilmi kendi içerisinde eritilmiş halde gösteriyordu. "Çin ilim ve medeniyetinin ananevi hümaniter yönü” gerçekliği benimsemenin başka bir şekli gibi olmuş, orada eski Çin mantığının matematikle ilişkisi

4 Rouzental F.Torjestvo Znaniya, M, 1978.

5 Bilim, fen, ilim, teknik, beceri.MK. 
hususi bir seciyede kendisini göstermiştir. İşte sırf buna göre de gerek Çin'de ve gerekse de Japonya ve onlarla komşu ülkelerdeki orta asır ilmi bugünkü bizim anladığımız ilmin kalıbı ile ölçülemiyor, bazen onu "başka sistemli ilim", bazen de "İlimsiz ilim", hatta "İlim olmayan ilim” ve başka türlü adlarla adlandırıyorlar (Uşkov, 1982: 150-152).

T.P. Grigoryevan'ın söylediklerine dayanarak, A. Uşkov şöyle bir genelleme yapıyor ki, biz öğreniyoruz ki, “Avrupa tipli” ilimden farklı olarak, (müellif “Avrupa tipli ilim” denince şimdiki ilmi anlaşıllyor) başka esaslara dayanan başkatipli ilim mümkündür ve Şarkta (burada daha çok Çin, Japonya, Hindistan ve onlarla komşu ülkeler dikkate alınıyor) teorik ve pratik (düşünüş sürecinde genelden özele gitme: tümdengelim) ilimden daha çok, ferdi tecrübeden ayrılmaz tecrübi ilim, teorik pratik ilim değil, sübjektif hissi tecrübe ile kopmaz bir bağla bağlı ilim ortaya çıkmıştır. Bununla beraber, aynı bu ilim olmayan ilmin, sadece gerçekliği anlaması başka türlü değil, hem de algılama usulü de başkadır. Bir şartla şunu da şöyle diyebiliriz ki, bu usul mantıki değil, "mantık üstüdür” ya da öyle duyguludur ki, her türlü şekli bilgiden kurtulmayı talep ediyor.

Âlimler hatta şöyle bir ihtimali ileri sürüyorlar ki, belki de Yunanistan'da formalaşan usul, Çinliler için çoktan geçilmiş bir merhale idi (Uşkov, 1982: 151). Ona göre de medeniyetlerin yaş farkını hiç bir zaman unutmamak gerekir ve bütün medeniyet ve ilimleri bir galiple, daha doğrusu bizim öğrettiğimiz usulle ölçmek, kıymet vermek doğru sayılmamalıdır. Bütün bunlarla beraber daha doğrusu âlimlerin bu fikir yürütmeleri ile belirli oranda anlaşmakla beraber, demeliyiz ki, bu tür kıymetlendirmeler yanlıştır. Meseleye daha derinden yanaşırsak, daha çok anlaşı1ır ki, şimdiki ilimde "Yunan Ananesi”, "Yunan Usulü” diye isimlendirilen ilmi anlayış, ya da “Avrupa Tipli İlim” ilk ortaya çıktığı şekle göre dünyada en eski olanıdır ve beşerin inkişaf tarihi boyunca kendisini ilerletmiş, üstünlük kazanmıştır. Bilindiği gibi, bu ilmin temelleri "Sümer'den başlayan tarihe" gidip ulaşır, onun yaşı daha eskidir ve birkaç ülkede (Örn: Irak, Mısır, İran vb.) ortaya çıkmış bilgileri kendisinde toplaya toplaya gelmiştir. Yunanistan'a ulaşınca da birkaç merhale daha geçirmiş, hiç de Çinliler için geçilmiş bir merhale değildir. Başka bir mesele de şudur ki, birçok ülkede, o cümleden Çin ve Japonya’da da, bedii edebiyat, umumiyetle humaniter ilimler, çok güçlü gelişme süreci geçirerek ilmi anlayışı da kendi içerisinde eritmiştir. Bedii edebiyatın "bu yönü”, orta asırlarda kendisini Azerbaycan, İran ve Araplarda da göstermiştir. Buna göre de XIV. yüzyılın büyük filozof ve tarihçisi İbn Haldun eski Arap şiiri hakkında şöyle yazıyor: "Şiir Arapların ilmini, tarihini, (ehbaruhum) ve felsefesini (hikmetuhum) kendisinde toplayan divanı (ne varsa her şeyi ile kendisinde toplayan.E. E) idi” (İbn Haldun, 1858, III hisse: 357). 
Kesin olan şudur ki, ayrı ayrı medeniyetlerde umumiyetle bilgi ve muayyen ilmi bilgiler, örneğin: riyaziyat, tıbb, tabiat uzmanlığı kendisini bu veya başka ölçülerde gösterir. Ancak, bunlar sistem şeklinde değil, ya da onun inkişafi muayyen yöne dayandığından dağınık haldedir. Asıl ilim için bu geçerli değildir. İlim iç içe kökünden bir biri ile bağlı olup, karışarak gelişen bilgilerin sistemidir. Bir dizi medeniyet fenomenleri, mesela, bedii edebiyat ilmi, bilgiye ulaşabilir ve hatta ilmin gelişmesine tesir de edebilir (hatta tarihte birçok ülkede böyle de olmuştur), ancak ilmin yerini kendisinden başka hiçbir şey tutamaz. Medeniyetin iki bağımsız ve büyük sahası olan ilim ile bedii edebiyatın karşılıklı bağlılıkları adetan iki şekilde kendisini gösterir:

a. Ya edebiyat ilimden yararlanır,

b. Ya da ilim yeri geldikçe bedii edebiyattan istifade eder.

Bu hal orta asırlarda Yakın ve Orta Şarkta kendisini sık sık göstermişti.

Mütenebbi (X.yüzyıl) (İbn Hallikân, 1978, c.I: 120, 123; el-Berkûk1, 1986, c.I: 4; Suûd Maḥmûd, 1994: 63; Durmuş, 2006, XXXII: 195; el-Yâzıc1, t.y.: 2; es-Se‘âlibı, 1983, I, 141; el-Bağdâdı, IV: 102; el Bağdâdı, 1989, II, 347; Şerefeddin, 1925: 214) ${ }^{6}$ Ebül Üla Müerri $(\mathrm{XI})^{7}$,Nizami (XII),

Fuzuli (XV) ve başka edebiyat dehalarının eserlerinde ilim öyle temsil edilmiştir ki, onların ayrıca da büyük âlim olduklarında hiç bir şüphe yeri kalmaz.

Ancak edebiyata getirilmiş "bu ilim ilmin kendisinin talebinden değil”, büyük şiirinin talebinden ve kendi devrindeki içtimai medeni hayatı birlikte kapsadığı ve takdim etmek isteğinden doğmuştur. Ona göre de Fuzuli diyor ki, "İlimsiz şiir cansız ceseddir. Ben kendi şiir gelinimi ilmin incileri ile süsledim”.

Dediğimiz gibi, ilim de kendi konumunda bedii edebiyattan muhtelif şekilde "kendi amacı için” yararlanmaya çalışmıştır. Bu yersiz bir durumda değildi. Ona göre ki, bedii forma ve ifadeler zor ilmi hakikatlerin kolay kavranmasına çok fazla yardım eder. Şöyle ki, dilde asırlar boyunca şekillenen, biriken ifadeler, aforizmler ${ }^{8}$ o dilde konuşan insanların düşüncesinde yer etmiş, aynı insanlar için anlaşılır ve "malum" olmuştur. "Meçhul" ilmi "malum" aforizmlerle insana ulaştırmak, ilmin öğrenilmesi ve benimsenilmesinde esas vasıtalardan biridir. İkincisi ise, bellidir ki, bedii edebiyat, özellikle de şiirin yüksek tesir

6 Abbasiler Dönemi Arap şiirinin en büyük temsilcilerinden, aynı zamanda bütün Arap edebiyatının da en önemli isimlerinden birisidir.MK..

7 Arap şairi ve alimi.MK..

8 Vecize, özdeyiş.MK.. 
gücüne malik olmakla birlikte, hem de zor ilmi fikirleri de insanlara ulaştırabilir (musiki daha yüksek tesire maliktir, ancak ilmi bilgileri insanlara ulaştıramıyor). İşte buna göre de ve bir de bununla bağlı olarak, Şark şiirinin (Arapça, Türkçe ve Farsça şiir) cemiyetin aşağıdan yukarı bütün sahalarını fethettiğine göre, çok fazla riyaziyat, tıp, felsefe (hatta ilimlerin tasnifine ait eserler) vb. nazıma göre yazılırdı (bunların sayısız numuneleri elyazma şeklinde dünyanın tanınmış kütüphane ve müzelerinde şimdi de mevcuttur).

Şöyle bir yerli soru sorulabilir, edebiyat ilmi veyahut ilim, bedii edebiyatl olabilir mi?

Kesinlikle! Üstelik bu ikisi çoğu yerde bir birini tamamlar. Hatta cesaretle diyebiliriz ki, gelecekte insani ilimlerle sayısal ilimler birleşsin. Tek bir sistem oluşsun. Bütün bunları göz önüne alıp diyebiliriz ki, "humanitar yönlü” medeniyetlerde (Ör. Çin medeniyetinde vb.) ilmin olması hiç de garip görünmemeli, onun "İlimsiz ilim” değil, gerçek ilim olduğu kabul edilmelidir. $\mathrm{Bu}$, ilmin muhtelif şekillerde, muhtelif usullerde tezahürü gibi anlaşılmalı, umumiyetle ilim “Avrupa Tipli” (çağdaş ilim şartlı olarak böyle adlandırılmıştır. Bazı edebiyatlarda bu Yunan ananesi ile oluşmuş ilim olarak da isimlendirilir) ilmin metresiyle ölçülmemelidir. Ancak, unutmamalıdırki, şimdilik ilmin en büyük ve kendisini daha çok geliştiren örneği, muayyen bir tarafgirliliğe saplanmadan, “Avrupa tipli” ilimdir. Bu ilmin, Aristoteles'in dediği ve şimdi de onaylandığ gibi, mahiyet ve mazmunu gerçek varlığ öğrenmektir. "Bu bilgide gerçek âlem, onun kanunları ve hususiyeti, alakaları ve münasebetleri açılır” (Nauka i Kultura, 1984: 10). Ancak bunu da göstermeliyiz ki, Çin, Japon, Hindistan, Yakın ve Orta Şark medeniyetinde başka şekilde kendisini gösteren ilmi bilgiler, onların başarıları, çağdaş “Avrupa” ilminden hala da uzakta kalmaktadır. Bu ise hala da tek dünya ilminin tam teşekkül olmaması demektir.

Peki, çă̆daş ilim ve yahut “Avrupa Tipli”, ya da "Yunan Ananeli” dediğimiz ilim, başkalarından hangi yönü ile farklanır, bu ilmin ilimliği neresindedir?

Kesinlikle diyebiliriz ki, ilim nedir sorusu ile “Avrupa” ilminin ilmiliği nerededir sorusu ayrı ayrıdır. Burada "Avrupa" ilminin geçip geldiği yol dikkate alınıp, o bakımdan da aydınlatmaya ve açıklamaya çalışılacaktır.

Bugünkü ilim, kadim Sümer, Akad, Babil, Mısır, Yunanistan, Türk, Hind, Çin, Orta Asır Şark ve Batı ilimlerinin varisidir. Bütün bu ilimler elene elene, seçile seçile belirli bir sisteme ulaşarak sistemleşmiş, inkişaf ederek bugünkü şeklini almıştır. Ona göre de seçile seçile diyoruz ki, eğer kadim Yunanlar, orta asır şark âlimleri, hatta XVII. yüzyılda Mehmed Emin Şirvânî (ö. 1036/1627) şarkta ve Francis Bacon (22 Ocak 1561-9 Nisan 1626) batıda 
şiirini, ince sanatını, ilahiyatını vb. çalışmasını kendi tasniflerinde ilim olarak adlandırmışlarsa da, çağdaş bir bakışla bunlar ilim olarak isimlendirilmemektedir. Uzun zaman hem Şarkta, hem de Batıda dinlere ait meseleler de ilmin içerisine ele alınmıştır. Bu onunla ilişkilidir ki, hala bu güne kadar ilme hepsinin kabul edeceği tek bir tarif ve isimlendirme yapılmamıştır. Daha doğrusu ilmi birkaç tarifle de belirginleştirmek mümkün olmadığından, onun hakkında denilen ayrı ayrı fikirleri bir yere toplamak mümkün olsaydı, birkaç cilt kitap yazılırdı. Ancak, bütün bunlarla beraber, umumi kabul edilmiş birkaç belirleme ilim hakkında muayyen doğru tasavvur yaratmaya imkân vermektedir.

İlm bilgilerin toplusu değil, sistemli, muayyen umumi ve hususi kuruluşudur. $\mathrm{Bu}$ kuruluş sadeden mürekkebe doğrudur. Buna göre de ilim, bilginin, idrak ve şuurun ayrı türüdür, onun kendi kanunları, gerçek varlığı kavramakta kendi usulleri vardır. İlim gerçek varlığın, mevcut ve kanuna uygun münasebetlerini aksettirir. Bilindiği gibi çağdaş ilimler üçe ayrilır:

- $\quad$ Tabii ilimleri,

- $\quad$ Cemiyet ilimleri (Humanitar İlimler),

- $\quad$ Teknik ilimleri.

İlmi anlayışa göre teknik ilimlerin tabii ilimlerden çıktığı kabul edildiğinden, esas ilim değil, yardımcı ilimlerden sayılır. Hatta XVII. yüzyılda büyük Azerbaycan âlimi Mehmed Emin Şirvanî bu fikri ileri sürmüştür. XX. yüzyılın büyük ilim nazariyecilerinden olan Marksist Japon âlimi Tosaka Dzün, çağdaş bilgide tabii ilimlerinin çok gerekli olduğunu göstermekle, onu şimdiki ilmin esas hususiyetlerinden biri sayıyor (Dzyun, 1983: 15).

Çağdaş ilmin geçip geldiği tarihe yakından bakınca şöyle bir ayrım görüyoruz:

Bilgi,

İlm bilgileri

Tabii ilimleri

Kesin ilimler.

Bu tür çözümlenme (analiz) hattı şimdiki ilmin ana hattıdır. Hatta bir dizi içtimai insani ilimlere de kesin ilimler uygulanır ve riyazi mantık, riyazi dilcilik, riyazi iktisat vb. ilim sahaları ortaya çıkar. 
Şimdiki ilimde, tabii ilimlerin önde olmasıyla beraber, bir yandan sanki müstakilleşiyor, başka bir yandan da içtimai ilimlere bir şekilde müdahale etmekle onu kendi "himayesine" "nüfuzu altına" almaya çalışıyor. Tabii ilimlerinin şimdiki iktisadi ve tekniki bakışa, askeri "yarışlara" oldukça fazla yardımı, onları yönlendirici mevkiye çıkarmış, onun kendisini içtimai ilimlerden, maddi yönden çok daha fazla zenginleştirmiş ve güçlendirmiştir. $\mathrm{Bu}$, çağdaş ilmin en büyük eksikliğidir, onu tek taraflı geliştirmektedir. Bu gidiş bugün büyük İLMIN zararınadır ve gelecekte cemiyete daha çok zarar verebilir. Sovyet Akademisyen V. Legasov ${ }^{9}$ sanki bunu dikkate alarak şöyle bir açıklama yapıyor: "Her bir âlim, tabiatla alakalı insani ilimlerle çok iyi eğitilmelidir. Ben buna çok fazla inanıyorum. Yoksa asıl âlim ister istemez kendi imkânlarını mahdudlaştırır. Her zaman bizim büyük hümanistlerin omzunda büyük "teknikçiler” olmuştur, böyle de olmalıdır. Ancak, çağdaş ilimde, bu muvazene bozulmuştur. Bu korkunçtur” (Nauka ne Terpit Odinoçestva, 23 Ocak 1987).

\section{KAYNAKÇA}

ABDURRAHMAN EL-BERKÛKI; (1986), Şerh Divan-u’l-Mutenebbl, Dâr-u“l-Kitâb-u'lArabl, Beyrut.

“ӘBU HӘNIFə” SÖZÜ; (1964), İslam Asiklopedisi, I.cilt, İstanbul.

“FİQH” SÖZÜ; (1964), İslam Asiklopedisi, V cilt, İstanbul.

“HADİS” SÖZÜ; (1964), İslam Asiklopedisi, I.cilt, İstanbul.

“HENEFILER” SÖZÜ; (1964), İslam Asiklopedisi, V cilt, İstanbul.

ABDULKÂDİR B. ÖMER EL-BAĞDÂDI; (1989), Hizânetu'l-Edeb ve Lubbu Lubâbi Lisâni’l- Arab, II, Mektebetu’l-Hanc1, Kahire.

ABDÜ'L-CÂBİR; (1981), Suud Mahmud, eş-Şi'r fi Rihâbi Seyfüddevle el-Hamdânı, Beyrut. ABRAROV, M.; (1961), Şariat i Yeqo Sosyalnaya Suşnost, Daşkənd.

AKSEKİ A. Hamdi; (1983), İslam Dini, İtikad, İbadet ve Ahlak, Ankara.

9 Valery Alexeyevich Legasov (Валерий Алексеевич Легасов; 1 Eylül 1936, Tula, -27 Nisan 1988, Moskova). 
ARISTOTEL; (1976), Soçineniya, I.cilt, Moskva.

AZERBAYCAN DILININ IZZAHLI LÜĞЭTI; (1964), I.cilt, Bak1.

AZERBAYCAN DILININ İZAHLI LÜĞӘTI; (1980), II.cilt, Bak1.

ÇALDAK, Süleyman; (2005), Taşköprülüzâde'nin Mevzû'âtu’l Ulûm’undaki İlimler Tasnifi Üzerine, Fırat Üniversitesi Sosyal Bilimler Dergisi, Cilt: 15, Sayı: 2, Elazı̆̆, s.115-146.

DURMUŞ, İsmail; (2006), “el-Mütenebbı”, Türkiye Diyanet Vakfi İslam Ansiklopedisi, XXXII, İstanbul, s. 195.

DZYUN, Tosaka; (1983), Teoriya Nauki, Moskva.

ӘBU ABDULLAH MӘНӘMМӘD; (1940), Rəhmətu-l-ummə fi Ixtilafi-l-Әimmə, Qahirə. ӘBU YUSİF; (1302h), Kitab al-Xərac, Qahirə.

EL-HATIB EL-BAĞDÂDI-EBÛ BEKR AHMED B. ALİ B. SÂBİT, Târıhu Bağdâd, I-XIV, Dâru'l-Kutubi’l-İlmiyye, Beyrut, ty, IV.

ES-SE‘ÂLIBI; (1983), Yetımetu'd-Dehr fı Mehâsini Ehli’l-Asr, I-V, Dâru'l-Kutubi’l-İlmiyye, I, Beyrut.

GÖLPINARLI, Ebülbaqi; (1967), Mövlana Müzesi Yazmalar Kataloqu, I.cilt, Ankara.

HACI HALİFE; (1890), Keşf ez-Zunun, II.cilt, İstanbul.

HACI XӘLİFӘ; (1890), Kaşf az-Zunun, I.cilt, İstanbul.

İBN HALLIKÂAN; (1978), Ebu'l-Abbâs Şemsuddın Ahmed b. Muhammed, Vefeyâtu'l-A'yân ve Enbâu Ebnâi'z-Zemân, I,Dâru Sâdır, Beyrut.

İBN XALDUN; (1858), Müqaddimə, III hissa, Paris.

İBN XӘLLIQQAN; (1299h), Vafayat al-Әyan, II.cilt, Misır.

İBN XӘLLIQAN; (1299h), Vafayat al-Әyan, III.cilt, Misir.

İSTORIYYA SREDNIX VEKOV; (1969), Xrestomatiya, Moskva.

KARIMOV, Q.; (1978), Şariat I Yeqo Sosyalnaya Suşnost, Moskva.

KELLE,V. J.; (1984), Nauka İ Kultura, Moskva, səh. 10-“Nauka Kak Fenomen Kulturl” Maqalosi.

LUKANIN, P. K. ; (1984), Orqanon Aristotelya, Moskva.

MASSE, A.; (1964), İslam, Bak1. 
MiSSE, A.; (1966), Musulmanskiy Renessans, Moskva.

MUHTASARUL-VIQQAYEET İLİ SOKRAHŞYENNIY VİQAET; (1845), Kurs Musulmanskoqo Zakonovedeniya Po Şkolu Xanefidov, Kazan.

MUSULMANSKIY MIR; (1981), Moskva.

NAUKA NE TERPITT ODINOÇESTVA; (1987), İvestiya Gazetesi, 23 Ocak 1987.

PRAVO V STRANAX SOSYALISTIÇESKOY ORIENTASİ;; (1979), Moskva.

PROZOROV, S. M.; (1980), Arabskaya İstoriçeskaya Literatura v İrake, İrane i Sredney Azii v VII-Seredine X vek, Şiitskaya Ístorioqrafiya, Moskva.

QLUXOV, Y.; (1980),Utro Nadejd, Pravda Qəzeti, 3 Mart 1980.

QURANIN MOZMUNU; (1980), N10, səh. 27-31.

ROJANSKIY İ. D, “Nauka v Kontekste Antiçnoy Kulturı” Makaləsi.

ROSENTHAL, Fran; (2003), Bilginin Zaferi, İslam Düşüncesinde Bilgi Kavramı, Çev. Lami Güngören, İstanbul.

ROUZENTAL, F.; (1978), Torjestvo Znaniya, Moskva.

SADAQDAR, M.; (1968),Osnovı Musulmanskoqo Prava, Moskva.

SAMİ, Şəmsəddin; Qamus əl-Elam, “Әbu Hənifə” Sözü.

SLOVAR RUSSKOQO YAZIKA (v çetırex tomax); (1983), I, II, izd. vtoroe Moskva.

ŞABANOV, F. S.; (1967), Qosudarstvenniy Stroy i Pravovaya Sistema Tursii v Period Tanzimata, Bak1.

ŞEREFEDDİN, Mehmed; (1984), “Mütenebb1)'den Evvel Şiir”, Dâru’l-fünûn Edebiyat Fakültesi Mecmuası, 3-4, 1925.

TOKAREV,S. A.; ( 1976), Dünya Xalqlarının Tarixində Din, M, səh. 533 (Rus Dilində)

USMANOV, M.; (1980), Quran Necə Yaranmışdır, Nauka i Reliqiya Jurnalı, N9, səh. 32-37 (Rus Dilində).

UŞKOV, A. M.; (1982), Utopiçeskaya Mısl v Stranax Vostoka: Traditsii v Sovremennost, Moskva, MQU, səh. 150-152. 